\title{
INVESTMENTS IN COMPANIES WITH NEGATIVE EQUITY: THE RETURN IS WORTH THE RISK?
}

\section{INVESTIMENTOS EM EMPRESAS COM PATRIMÔNIO LÍQUIDO NEGATIVO: O RETORNO VALE O RISCO?}

\author{
JOSÉ ANTONIO CESCON \\ Professor na Universidade Estadual do Oeste do Paraná (Unioeste) \\ Doutor em Ciências Contábeis - Universidade do Vale do Rio dos Sinos (Unisinos) \\ Orcid: http://orcid.org/0000-0002-8338-7743 / E-mail: cescon@cescon.adm.br \\ Av. Tarquínio Joslin dos Santos - Jardim Universitário das Américas \\ Foz do Iguaçu/PR - Brasil, CEP: 85870-650 \\ ROBERTO FROTA DECOURT \\ Doutor em Administração - Universidade Federal do Rio Grande do Sul (UFRGS) \\ Professor do PPG em Ciências Contábeis e Finanças - Unisinos) \\ Orcid: http://orcid.org/0000-0002-9419-498X / E-mail: rfdecourt@unisinos.br \\ LUCIANA DE ANDRADE COSTA \\ Coordenadora e professora do PPG em Economia - Unisinos \\ Ph.D. em Economia - Drexel University \\ Orcid: http://orcid.org/0000-0002-7575-2405 / E-mail: landradec@unisinos.br
}

Submissão: 08/07/2020. Revisão: 13/10/2020. Aceite: 29/12/2020. Publicação: 24/03/2021. DOI: http://dx.doi.org/10.22277/rgo.v14i2.5637

\begin{abstract}
This study analyzed the return and risk of an investment portfolio, composed only of shares of companies listed in B3 that presented Negative Equity (NE), in the period from 1998 to 2019. Considering the Efficient Market Hypothesis (FAMA, 1970), the rationality of investors, the stock market on the stock exchange, in relation to companies with PLN, theoretically should not be active or provide abnormal positive returns to investors, since, technically, companies would be insolvent. The method used was to build a portfolio for assets that had at least one year of trading on the stock exchange and had NE in this period. The number of shares (assets) was fluctuating, starting with 2 and ending with 44 shares. The results of the Portfolio were compared to a riskfree investment (Interbank Deposit Certificate - CDI) and a similar risk investment (Brasil 50 Index - IBrX50), this as a control portfolio. The results found indicate that it is possible to obtain abnormal positive results, but do not meet the risk and return ratio when compared to a risk-free investment. However, when compared to other risky investments, investing in companies with NE may make sense, since a portfolio with no judgment criteria presents a more attractive risk and return ratio than stock indexes. This study contributes to the literature, as it brings to the academic world the universe of companies with $\mathrm{NE}$, notably concerning the returns that these companies can provide to investors and, also for being an unprecedented study in this approach in Brazil.
\end{abstract}

Keywords: Investment portfolio. Risk-return. Negative equity.

Este é um artigo publicado em acesso aberto (Open Access) sob a licença Creative Commons Attribution, que permite uso, distribuição e reprodução em qualquer meio, sem restrições desde que o trabalho original seja corretamente citado. 


\section{RESUMO}

Este estudo analisou o retorno e risco de uma carteira de investimento, composta somente por ações de empresas listadas na B3 que apresentaram Patrimônio Líquido Negativo (PLN), no período de 1998 a 2019. Considerando a premissa da Hipótese do Mercado Eficiente (FAMA, 1970), a racionalidade dos investidores, o mercado de ações, sobre as empresas com PLN, teoricamente não deveria ser ativo ou proporcionar retornos positivos anormais aos investidores, já que, tecnicamente, as empresas estariam insolventes. O método utilizado, foi a construção de uma carteira por ativos que possuíram pelo menos um ano de movimento na bolsa e estavam com PLN neste período. O número de ações (ativos) foi flutuante, iniciandose com 2 e terminando com 44 ações. Os resultados da Carteira, foram comparados, à um investimento livre de risco (Certificado de Depósito Interbancário - CDI) e a um investimento de risco similar (Índice Brasil 50 - IBrX50), este como carteira de controle. Os resultados encontrados apontam que é possível obter resultados positivos anormais, porém não atendem a relação risco e retorno se comparado a um investimento livre de risco. Todavia, quando comparado com outros investimentos de risco, o investimento em empresas com PLN pode fazer sentido, pois uma carteira sem nenhum critério de julgamento apresenta relação risco e retorno mais atraente que os índices de ações da B3. Este estudo contribui com a literatura, pois traz para discussão do meio acadêmico o universo das empresas com PLN, notadamente em relação aos retornos que estas empresas podem proporcionar a investidores e ainda por ser um estudo inédito nesta abordagem no Brasil.

Palavras-chave: Carteira de Investimento. Risco e Retorno. Patrimônio Líquido Negativo.

\section{INTRODUÇÃO}

In the capital market, for the investor, the decision to buy or maintain a share is based on the gains provided and/or expected from this investment. Thus, if these gains are related to the company's future profits, the purchase or maintenance of these shares must be made based on those future profits. However, the capital market has presented companies with negative equity (NE), that is, even close to its liquidation, it has an active market and still has a positive market value.

Considering that there is a relevant range of reasons why companies can present $\mathrm{NE}$, investors can differentiate those with the power to be profitable in the future from those that do not have the same perspective. As a result, the former will have a positive market value. Therefore, the market has considered some other value attributes present in these companies.

Studies have shown an increasing frequency of companies with recurrent losses and (NE) for one or more periods (JAN; OU, 2012). However, researchers have excluded these firms from their samples, relying on the argument that they are few and that their exclusion would not have a significant effect on any data-processing application (BROWN; LAJBCYGIER; LI, 2008). Another argument to exclude companies with NE mentioned by Brown et al. (2008), concerns the high risk of bankruptcy. Besides that, when including companies with NE in a sample with companies with Positive Equity (PE), this skews the results, so the researchers when using the rule of thumb in the identification and correction of outliers of a sample, exclude companies with NE (GRILLO et. al., 2016).

Contrary to the argument, Fama \& French (1992); Hayn (1995); Collins, Pincus \& Xie (1999); Brown et al. (2008); Jan \& Ou (2012); Hou, Zhang \& Zhuang (2015); Ang (2015); and 
Investments in companies with negative equity:

the return is worth the risk?

Luo et al. (2019), point out, in addition to a larger and growing incidence of companies with $\mathrm{NE}$, the importance of including these companies in asset pricing models.

Brown et al. (2008), also found that the omission of such companies is significant. Using past returns to classify these stocks into appropriate value statements, they have shown that, once included, NE plays a crucial role in changing the magnitude of the return premium. Thus, the valuation of companies, whose results and equity are negative, emerges as a new challenge for researchers (JAN; OU, 2012). In this context, it should be noted that the literature on the modern financial theory of asset pricing and risk/return analysis in investments was developed based on Markowitz's Theory of portfolios (1952), through Capital Asset Prices Model (CAPM) from Sharp (1964) and Lintner (1965), which gave rise to the Sharpe Index, and from Ross (1976), advancing with the Arbitrage Pricing Theory (APT). Since then, there is a vast literature that seeks to understand and explain the results found, mainly to predict a future trend (results).

The models form the basis of the Efficient Market Hypothesis (EMH), by Fama (1970) and by Fama \& French (1992 and 1993), which presents two relevant premises. The first ensures that bond prices correctly reflect any information available to investors, and the second asserts that negotiators with active strategies will find it difficult to overcome those with passive strategies (BODIE et al., 2015). The most common model for evaluating a running business is based on the observation that an investor expects a return that, in addition to preserving capital, includes dividends. Thus, if the investor's estimate of the shares' value exceeds the market price, the stock will be considered undervalued and, therefore, a good investment for that investor (BODIE et al., 2015).

In this perspective, this study sought to evaluate the performance of a portfolio assembled with shares of companies listed in $\mathrm{B} 3$ that presented NE, considering the period from 1998 to 2016 and whether this performance is consistent with the risk-return ratio recommended by Modern Theory of Finance. In this sense, based on the accumulated return provided by the Portfolio, is it possible to affirm that the investment in companies that have and/or had NE is viable?

This study is justified by the fact that annually on average 11percent of the companies active in $\mathrm{B} 3$ have NE, the growing academic and professional interest in these companies, notably at the international level, and by the absence of studies in Brazil with companies that have NE and positive market value. Another point that outlines the context of this work is associated with how economic theory deals with this phenomenon. It is observed that the understanding of the modern model of finance presupposes the understanding of the Portfolio Theory approach (MARKOWITZ, 1952); the Capital Asset Pricing Model - CAPM (SHARPE, 1964; LINTNER, 1965); and the Efficient Market Hypothesis (HME) (FAMA, 1970).

In addition to this introductory section, this article contains section 2, bibliographic review; section 3 with the methodology used; section 4 with the presentation and discussion of the results; and section 5 for final remarks.

\section{LITERATURE REVIEW}

This section provides a brief overview of the Modern Finance Theory, including the $\mathrm{EMH}$ and Arbitrage Pricing Theory (APT), and NE, which are fundamental to the theoretical support of this research. 


\subsection{MODERN THEORY OF FINANCE}

The Modern Finance Theory is composed of various theories, based on neoclassical economic theory. It assumes that: i) investors act rationally in the market, are averse to risk, seek to maximize expected utility given rational expectations and perfect information; ii) markets are highly efficient; and iii) investors exploit all arbitrage opportunities. It also assumes agents capable of deciding strictly according to unlimited rationality, besides being structured methodologically according to the Theory of Expected Utility and having no biases about the future (SHLEIFER, 2000).

Modern finance has been developed since 1950 within the economics departments of universities. According to Haugen (2000), the main literature from that time on are still adopted as finance models, among which stand out those of Markowitz (1952), Simon (1957), Sharpe (1964), Lintner (1965), Fama (1970), Merton (1973) and Ross (1976). Among the theories from the modern literature on finance are EMH and ATP, and which are discussed below.

\subsubsection{Efficient Market Hypothesis}

The EMH (Fama, 1970) was developed based on studies by Markowitz (1952) and Sharpe (1964). This hypothesis considers that, in the capital market, asset prices reflect their correct values, that all information is available and that any deviations are corrected through arbitrage (JENSEN, 1978). For Shleifer (2000, p. 5), EMH assumes that "when people are rational, markets are efficient by definition." In addition, Fama (1970) highlights some assumptions for a market to be efficient, such as the absence of transaction costs, equity in access to available information, and homogeneity of investors' expectations regarding the probabilities of asset returns.

The EMH developed by Fama $(1970,1991)$ was based on the concepts developed by the articles of Roberts (1959) and Osborne (1959), which brought empirical findings of the randomness of stock prices. These authors have found that the relevant information of the companies traded in the market is incorporated into the prices of the assets and that the best estimate for the price of a security is its current price. For Easley \& O'Hara (2004), in equilibrium, the quantity and quality of information affect asset prices. With technological developments, which incorporated robots in the role of traders, a recent study by Zhou, Elliott \& Kalev (2019), found that algorithmic traders contribute more to the permanent price processes and less to the transient pricing errors compared to other traders overall, during periods of high individual stock volatility, and on market-wide stress days.

An efficient market, according to Fama (1970), is one whose prices always fully reflect the available information. Fama (1991) states that price behavior follows the so-called random walk, so agents cannot create mechanisms for obtaining abnormal results at predetermined periods. Thus, if the behavior of asset prices follows a random path, it is natural that their variations are unpredictable. In the sense pointed out, for Fama (1970), prices represent the true and precise sign of the value of assets. In this way, no investor can use strategies or differentiated information to obtain advantages in the capital market before the other investors, even if they are the private information of the company issuing the title (STRONG, 2007).

According to Strong (2007), the efficiency of markets does not occur autonomous or naturally. The agents' action makes the market more, or less efficient. When looking for abnormal gains, agents contribute to the efficiency of the market as a whole because, by

RGO - Revista Gestão Organizacional, Chapecó, v. 14, n. 2, p. 229-250, maio/ago. 2021. 
Investments in companies with negative equity:

the return is worth the risk?

constantly negotiating, they eventually nullify the advantages that an investment scheme might provide (STRONG, 2007).

The definition of market efficiency should be specific and precise as to the market since it is likely the market is not going to be efficient for all agents (TIMMERMANN; GRANGER, 2004). Fama (1970), to test the forms of market efficiency, divided the tests based on three sets of information: a) past information (historical prices), weak form; b) Publicly available information, medium-strong form, and; c) The whole set of information (past, public and private information) is strong form.

In Brazil, several studies have sought to prove the EMH in its three forms. Studies by Farias, Ceretta \& Rosa (2009) concluded the existence of a weak form of market efficiency. Müller, Righi \& Ceretta (2015) failed to prove this type of efficiency, while Ferreira \& Oliveira (2014); Roma, Ferreira \& Amaral (2015) rejected the EMH in the weak form. Antunes, Lamounier \& Bressan (2006), and Gabriel, Ribeiro \& Ribeiro (2013) identified a medium-strong form EMH, Rêgo \& Mussa (2008) rejected medium-strong form EMH. The strong form of EMH was rejected in the studies of Rochman \& Eid Júnior (2007). EMH's premise is that balance in competitive markets is made up of fully rational investors. This balance is also composed of the actions of the arbitrators.

\subsubsection{Arbitration Pricing Theory}

The Arbitrage Pricing Theory (APT) was developed by Ross (1976). Like the CAPM, the APT provides for the Security Market Line (SML), which associates the expected returns to the risk, but it does it differently. The APT relies on three main propositions: (1) securities returns can be described by a factor model; (2) there are sufficient securities to diversify the idiosyncratic risk; and (3) well-functioning bond markets do not allow arbitrage opportunities to remain (BODIE et al., 2015).

To demonstrate the importance of arbitrage in the market efficiency, a stock that is overvalued relative to its fundamental value (net present value of expected cash flows) is taken as an example, which, according to $E M H$, is a result of the action of non-rational investors in the market. By noticing this distortion, arbitrageurs could sell this asset and simultaneously buy another similar stock to protect yourself from your risk. This action would bring the price of the overvalued share to levels compatible with its fundamental value (JENSEN, 1978; BODIE et al., 2015).

APT has an advantage over CAPM due to its flexibility, however, it is more difficult in application since the factors to be used are very difficult to identify. While the CAPM emphasizes efficient diversification and neglects the unsystematic risk, the APT uses the naive diversification upon the law of large numbers and therefore neglects essential risks, which is a part of the systematic risk (NGUYEN et al., 2017).

\subsection{NEGATIVE EQUITY}

Companies with NE have little chance of survival, being, in other words, ready for abandon (JAN; OU, 2012; BROWN et al., 2008; ANG, 2015). Studies examining these firms and their market value gained relevance in the mid-1990s. There are, however, few studies reporting on NE. Jan \& Ou (2012), based on studies on the relationship between return and value, found that, unlike companies reporting profits, the correlation between these two measures is negative. They also point out that equity is a powerful explanatory variable for market value when profits are negative. 
Hayn (1995), on the other hand, points out that companies reporting losses have lower response coefficients than firms reporting profits. The author raises the hypothesis that this is because shareholders always have an option to liquidate the company and as a result, damages cannot persist indefinitely. It also shows evidence that the frequency these companies report losses has increased over time.

Already Collins et al. (1999), report that, for US companies, net worth is more relevant than return when losses are reported. Similarly, a document that, when the effect of the observations of losses is removed from the sample, the relative explanatory power of earnings increases and decreases in equity. According to these authors, the inclusion of firms with losses in the sample of a study, comparing the relevance of the relative value of profits and net worth between countries, may affect the relevance of the observed relative value of profits and the net worth between them countries and the related conclusions.

For Donnelly (2014), there is no consensus as to why book-to-market is positively related to future stock returns. A company that has a high book-to-market rate is relatively vulnerable, and its low outlook is reflected in a low market value relative to its book value (DONNELLY, 2014). However, Donnelly (2014) argues that the predictive power of book-tomarket for a return does not depend on a pricing asset or the risk of a rational interpretation of book-to-market.

As for the stocks with an upward trend, most of their valuation depends on the expectation of present and future profitability, and not on differential optimism. This makes the stocks more responsive to losses. Evidence valuation models that value stocks are insensitive to losses, which is corroborated by the failure to find a relationship between the ratio and the book-to-market forecast review after a loss report, although the value of the shares is susceptible to losses that, on average, are much higher in relative terms than those in stocks (DONNELLY, 2014).

\section{METHODOLOGICAL PROCEDURES}

The sample of this study consists of assets (stocks) of companies listed in B3 that have or had NE in at least one quarter and that are or have been active in the market for at least one year in the period of this study (December 1997 to December 2018). For the sample, initially, all the companies that are or were part of the B3 were identified. To do so, we consulted the ECONOMATICA ${ }^{\circledR}$ database, for the period between the 4th quarter of 1997 (the initial base period for the selection of assets to compose the data analysis) and the 4th quarter of 2018. Then, it was selected the assets of the companies that had NE in at least one quarter in the period. Once the companies were selected, their assets were analyzed until the 4th quarter of 2019.

Also, for purposes of the study, the most liquid asset of each company listed in B3 was chosen. Therefore, only one type of asset (share) per company. Table 1 summarizes the sample selection.

After the selection of the assets that presented enough movement for analysis and which had at least one monthly transaction for at least one (1) year, this transaction must coincide with the period in which the company had a NE, (quotations) of the assets belonging to the sample, from which the construction of a monthly index of each asset was started. 
Investments in companies with negative equity:

the return is worth the risk?

Table 1 - Summary of the selection of assets/companies

\begin{tabular}{|c|c|c|c|c|}
\hline \multirow{2}{*}{ Item } & \multicolumn{3}{|c|}{ Asset Type /Class } & \multirow[t]{2}{*}{ Overall } \\
\hline & ON & PN & Others & \\
\hline Assets (shares) in B3 in the analyzed period & 673 & 594 & 38 & 1.305 \\
\hline Companies with assets in the period & 461 & 300 & 19 & 780 \\
\hline Companies with negative equity in the period & 114 & 104 & 05 & 223 \\
\hline Companies excluded - Finances and Insurance & 05 & 05 & - & 10 \\
\hline Companies excluded - Public & 03 & 01 & - & 04 \\
\hline $\begin{array}{l}\text { Companies excluded due to a lack of data in the period in which } \\
\text { they had negative equity }\end{array}$ & 09 & 03 & 02 & 14 \\
\hline Companies excluded due to absence or insufficient data & 57 & 42 & 03 & 93 \\
\hline $\begin{array}{l}\text { Companies excluded because they present data available after } \\
\text { one year or more of their entry in negative equity }\end{array}$ & 06 & 04 & 00 & 10 \\
\hline Companies belonging to the sample & 34 & 49 & 00 & 83 \\
\hline
\end{tabular}

Source: Research data.

For the monthly index of each asset, we identified the quarters in which the company started to have NE. As the database of the company's Equity is quarterly, the asset becomes part of the sample on the 1st day of the beginning of the next quarter. Thus, for example, the assets of the companies Café Brasília, code CAFE4, and Wetzel S/A, code MWET4, which presented negative equity in the fourth quarter of 1997, began to have their data analyzed from the first day with data available in the 1st quarter of 1998. The monthly index of changes in asset prices was calculated using the last quotation value in the month divided by the first quotation value of the month (in the initial month of the collection of quotations) and the last quotation value in the month divided by the last quotation value of the previous month (in other months).

\subsection{THE PORTFOLIO: CONSTRUCTION, VALUATION, AND MANAGEMENT CRITERIA}

The portfolio considered the companies with NE in the fourth quarter of 1997, with historical quotations as of January 5, 1998 (1st day with historical quotation in the database). To be in the portfolio the company must have had NE in the previous quarter. Some companies had NE in the previous quarter, but they did not have historical quotation data in the initial month of the next quarter or even in subsequent quarters. Thus, this company became part of the portfolio in the month that had such historical data, as long it still had a NE.

In this study, the portfolio was composed of assets under specific conditions. But in general, how many assets does a portfolio adequately diversify? For Evans and Archer (1968), the ideal number to be held in the portfolio is 10 assets. Statman (1987) contested the study of Evans and Archer (1968). For this author, the ideal number is between 30 and 40 assets. In Brazil, Ceretta and Costa Jr (2000) concluded that the number of assets should vary from 12 to 18 assets.

The portfolio composition was changeable regarding the number of assets, starting with 2 assets in January 1998 (1st quarter /1998) and ending with 44 (forty-four) assets in December 2019 (4th quarter /2019). Each composition of the portfolio last 3 (three) months, for the periods from January to March; April to June; July to September; and October to December. Given the number of assets in the portfolio was not fixed, it was necessary to adopt a weighting criterion to assign value to each asset at the beginning of the new quarter.

Because the composition of the portfolio is changing, the value criterion for each asset was an investment of equal weight in the initial two assets of the portfolio in the first quarter of 1998. By the criterion adopted, at the end of this first quarter, the redemption of the 
investment and the reapplication in the portfolio at the beginning of the following quarter with equal weights in each asset were made, which were part of the new composition of the portfolio

The criterion adopted was that, at the end of each quarter, the redemption of the investment would be carried out and reapplied in the portfolio with equal weights in each asset that was part of the portfolio's composition. This criterion is different, for example, from the IBrX50 index, from B3, since it has a fixed number (50 assets) and a period of 4 months and, at the end period, the portfolio is rebalanced, and the assets have different weights (B3, 2020).

Also, it was established that the asset would come out of the portfolio, when a takeover bid, Bankruptcy, or Exclusion occurred through B3. In cases where a takeover bid occurred, the redemption value was reinvested in the portfolio and, in the cases of Bankruptcy or Exclusion, these values were recognized as losses.

To avoid arbitrariness, and to maintain the consistency of the asset valuation criteria in the portfolio, only the two initial assets (which entered into the portfolio in January 1998) were valued at $\$ 100.00$ each. The two assets that entered in February/1998 and the two in March/1998 only had investments at the beginning of the following quarter. At the end of the first quarter, the investment was made, and it was reinvested in the second quarter on eight assets, six assets from the first quarter, and two new assets to the portfolio in April 1998. Table 2 shows the asset valuation methodology in the portfolio composition.

Table 2 - Initial Composition of the Investment Portfolio

\begin{tabular}{|c|c|c|c|c|c|c|c|c|}
\hline $\begin{array}{l}\text { Month / } \\
\text { Year }\end{array}$ & $\begin{array}{c}\text { Initial } \\
\text { Investmen } \\
\mathrm{t}\end{array}$ & $\begin{array}{c}\text { Index } \\
\text { Jan./199 } \\
8\end{array}$ & Update & $\begin{array}{c}\text { Index } \\
\text { Feb./199 } \\
8 \\
\end{array}$ & Update & $\begin{array}{c}\text { Index } \\
\text { Mar./199 } \\
8 \\
\end{array}$ & $\begin{array}{c}\text { Update / } \\
\text { Redemption }\end{array}$ & $\begin{array}{c}\text { Reinvestmen } \\
\mathrm{t}\end{array}$ \\
\hline CAFE4 & $\$ 100$ & -0.067 & $\$ 93.30$ & -0.224 & $\$ 72.40$ & -0.625 & $\$ 27.15$ & $\$ 25.61$ \\
\hline MWET4 & $\$ 100$ & 0.000 & $\$ 100.00$ & 0.563 & $\$ 156.30$ & 0.137 & $\$ 177.71$ & $\$ 25.61$ \\
\hline ORIO4 & & & & 0.563 & $\$ 0.00$ & 0.560 & $\$ 0.00$ & $\$ 25.61$ \\
\hline EALT4 & & & & 0 & $\$ 0.00$ & 0 & $\$ 0.00$ & $\$ 25.61$ \\
\hline ITPS4 & & & & & & 0.067 & $\$ 0.00$ & $\$ 25.61$ \\
\hline TRBR4 & & & & & & -0.143 & $\$ 0.00$ & $\$ 25.61$ \\
\hline SIFC4 & & & & & & & & $\$ 25.61$ \\
\hline CPFL4 & & & & & & & & $\$ 25.61$ \\
\hline Summation & $\$ 200$ & & $\$ 193.30$ & & $\$ 228.70$ & & $\$ 204.86$ & $\$ 204.87$ \\
\hline
\end{tabular}

Source: Research data.

The analysis of the Portfolio's results was in relation to: the $\mathrm{CDI}$, considered a risk-free investment; IBrX50 to (B3 index composed of 50 stocks) as an investment with similar risk (medium/high); and inflation for the period, through the Broad Consumer Price Index (IPCA), which is the official inflation index in Brazil.

In addition to this analysis, the comparison was made with portfolio exits of the companies that returned to Positive Equity (PE) in 4 (four) different moments: 1st quarter after return to PE; 2 nd quarter after return to PE; 1 (one) year after return to PE; and 2 (two) years after the return to PE. In all of these exit simulations, the same balance criterion of the portfolio was adopted. To analyses the risk-return, the Sharpe Index was used in the results of the investment portfolio.

\subsection{SHARPE INDEX}


Investments in companies with negative equity:

the return is worth the risk?

Investment diversification typically requires the acceptance of a certain risk in exchange for the prospect of obtaining a higher rate than a risk-free investment. In this way, investors determine the price of risky assets so that the risk premium is proportional to the risk of that expected excess return; therefore, it is better to measure the risk by the standard deviation of the excess returns, and not simply by means of the total returns of each investment (BODIE et al., 2015).

The trade-off between reward (the risk premium) and the risk (measured by the standard deviation) indicates that the attractiveness of a portfolio is being measured based on the risk premium index and standard deviation of the excess returns. This measure of reward/volatility (first proposed by William Sharpe, called the Sharpe Index) is widely used to evaluate the performance of investment managers (BODIE et al., 2015).

Is there an adequate number to determine a good Sharpe Index? For Bodie et al. (2015), the ideal is that the Sharpe Index to be equal to 1; but in the long run, it is difficult to find a multimarket fund or a portfolio with Sharpe Index above 1 . This number indicates that, for every $1 \%$ of excess return, the fund showed an increase of only $1 \%$ risk.

For the Sharpe Ratio can be used by investors as a security measure when choosing an application that has some risk, Hodges, Taylor \& Yoder (2003), proposed to be calculated according to the following criteria:

i) To consider a minimum number of 24 data points, that is, of surplus returns. There may be considered 24 monthly surplus returns (period of two years), etc. The longer the period, the more reliable the index.

ii) The indexer chosen is the one whose variation will be compared with the nominal return of the fund (portfolio) to calculate the excess return and that must have a relation with the segment to which the fund belongs (or with the fund's profitability objective). It should provide the income the fund would get if it were not at risk and therefore considered risk-free.

In this study, the Sharpe Index was calculated for the entire period of the portfolio and in periods of 24 months (two years). The difference in any specific period between the "real" rate of return on a risky asset and the risk-free rate is called excess return (BODIE et al., 2015).

\section{RESULTS}

\subsection{THE INVESTMENT PORTFOLIO}

The purpose of the portfolio's construction was to verify if there were excess returns and if the portfolio's return, against a risk-free investment (CDI) and a risk investment similar to the portfolio (Index IBrX50), had a premium of appropriate risk for this excess return.

Within the analyzed period, the first quarter of 1998 had the lowest percentage (8.21\%) of companies with NE (33 out of a total of 402 companies). In the second quarter of 2004 , it was the largest percentage (16.18\%) of companies with NE (67 out of 414 companies). Relative to the number of companies participating in B3, the 4th quarter of 2019 was the period with the lowest number of companies (382 listed), and the 2nd quarter of 2007 was the one with the highest number of companies (464 listed).

About the entries of listed companies, the largest number of entries occurred in 1998 (88 companies); 2006 (41); 2001 (37), and 2007 (35). On the other hand, the smallest number of company entries in B3 occurred in 2015 (03); 2013, and 2017 (04). Regarding the exits, the occurrences in greater number were in the years of 2000 (26); 2008 (24); 2002 (23); 2003 (23) and 2005 (22), with fewer occurrences occurring in 2013 (08) and 2011 (13). 
There was a continuous growth of companies with NE in relation to the total of companies from 1998 to 2002. From 2003 to 2006, there was a stability in this relation that began to decrease from 2007 until 2010, with a new stabilization between 2011 and 2014, returning to have a small high in 2015.

In Table 3, are presented the codes of the shares-companies listed on B3 in the sample of this study.

Table 3 - Code of shares/companies with negative equity

\begin{tabular}{l|r|l|r|l|r|l|r|l|r}
\multicolumn{1}{c|}{ Asset } & \multicolumn{1}{c|}{$\boldsymbol{\Delta}$} & \multicolumn{1}{c|}{ Asset } & \multicolumn{1}{c|}{$\boldsymbol{\Delta}$} & \multicolumn{1}{c|}{ Asset } & \multicolumn{1}{c|}{$\boldsymbol{\Delta}$} & \multicolumn{1}{c|}{ Asset } & \multicolumn{1}{c|}{$\boldsymbol{\Delta}$} & \multicolumn{1}{c}{ Asset } & \multicolumn{1}{c}{$\boldsymbol{\Delta}$} \\
\hline AELP3* & $18 / 79$ & CREM4** & $6 / 25$ & ILMD4* & $5 / 56$ & OGSA3* & $5 / 9$ & SJOS4* & $49 / 88$ \\
\hline ARLA3* & $11 / 45$ & CTKA4* & $25 / 88$ & IMBI4* & $32 / 71$ & OGXP3* & $20 / 47$ & SNSY5* & $50 / 88$ \\
\hline ARTE4** & $8 / 34$ & DOCA4* & $26 / 66$ & INEP4* & $25 / 88$ & ORIO4** & $11 / 11$ & SOLO4** & $1 / 24$ \\
\hline ASSM3** & $9 / 38$ & EALT4* & $49 / 88$ & ITPS4** & $11 / 11$ & OSXB3* & $28 / 46$ & STRP4** & $6 / 49$ \\
\hline ATMP3* & $9 / 64$ & EKTR3* & $4 / 83$ & JBDU4* & $6 / 88$ & PDGR3* & $14 / 54$ & TASA4* & $20 / 88$ \\
\hline AVIL3** & $4 / 52$ & ESTR4* & $74 / 88$ & JFEN3* & $1 / 84$ & PMAM3* & $16 / 88$ & TEKA4* & $58 / 88$ \\
\hline AZEV3* & $47 / 88$ & FGUI4* & $36 / 37$ & KEPL3* & $4 / 88$ & PMET6** & $69 / 69$ & TENE5* & $41 / 84$ \\
\hline BAUH4* & $2 / 86$ & FRIO3* & $1 / 53$ & LETO5** & $18 / 42$ & PRVI3** & $1 / 44$ & TOYB4* & $61 / 85$ \\
\hline BEEF3* & $12 / 61$ & FRTA3* & $14 / 70$ & LOGN3* & $10 / 53$ & RCSL4* & $55 / 88$ & TRBR4** & $7 / 14$ \\
\hline BIOM3* & $24 / 72$ & FTSE4** & $3 / 11$ & LUPA3* & $12 / 49$ & REDE4* & $7 / 85$ & TXRX4* & $55 / 88$ \\
\hline BOBR4* & $63 / 88$ & GOLL4* & $21 / 65$ & LUXM4* & $5 / 88$ & RHDS3** & $6 / 67$ & VAGV4** & $24 / 36$ \\
\hline BSEV3* & $9 / 32$ & GPCP3* & $5 / 86$ & MGEL4* & $26 / 88$ & RIPI4** & $2 / 42$ & VIVR3* & $17 / 49$ \\
\hline BTTL4* & $31 / 88$ & HGTX3* & $4 / 88$ & MMXM3* & $28 / 56$ & ROSI4** & $4 / 19$ & VPSC4** & $34 / 35$ \\
\hline CAFE4* & $57 / 57$ & HOOT4* & $56 / 86$ & MNDL3* & $18 / 88$ & RPMG3* & $44 / 88$ & VPTA4** & $23 / 25$ \\
\hline CARB5** & $1 / 21$ & IDNT3* & $6 / 68$ & MNSA4* & $2 / 33$ & SCLO4* & $63 / 88$ & VULC3* & $24 / 88$ \\
\hline CELP3* & $1 / 73$ & IGBR3* & $51 / 88$ & MPLU3* & $1 / 37$ & SIBR7** & $9 / 16$ & & \\
\hline CPFL4** & $8 / 20$ & IGUA6** & $13 / 69$ & MWET4* & $69 / 88$ & SIFC4** & $8 / 24$ & & \\
\hline
\end{tabular}

* - Asset Activ in 12/31/2019 at B3

** - Asset Canceled in 12/31/2019 at B3

$\Delta$ - Number of observations in NE of total observations of the asset between 1998 to 2019 .

Source: Research data.

Of the shares listed in Table 3, it was identified: i) the number of quarters in which each one had its shares traded on the stock exchange; ii) the number of quarters that presented $\mathrm{NE}$; iii) how many times in the period object of the study it had NE; iv) and the number of times that reversed this situation, that is, it started to have Positive Equity (PE).

To analyze Table 3, it is important to point out that the sample was composed of companies that entered and exited the capital market during the period of this study. Thus, there are companies with a larger number of observations, such as the RCSL4, JFEN3, CELP3, FJTA4, INEP4, INEP4, KEPPL4, SNSY5, MWET4, BTTL4, RPMG4, BOBR4, EALT4, PMAM3, HGTX3, CTKA3, SCLO4, SJOS4, TEKA4, TXRX4, VULC3, LUMX4, IGBR3, and ESTR4, with 73 quarters of data. This corresponds to the maximum number of quarters observed and of companies with a smaller series of observations, such as asset OGSA3, with only 9 quarters observed, and assets ITPS4, ORIO4, and FTSE4, with 11 quarters observed.

Regarding the number of quarters that the companies remained with NE, we highlight the PMET6 asset, which had 69 observations, and CAFE4, with 57 observations, all of them with negative equity. To have a NE and return to the PE, the asset ESTR4 stands out, with 7 entries in negative equity and 6 returns to the PE, and the asset PMAM3, with 4 inflows and 4 returns. It should also be noted that the assets that had observations with NE in intermediate quarters, that is, these companies closed the year of the observation with PE. These assets and the quarters of observation of the NE were as follows: SOLO4 3rd / 2002; CELP3 2nd / 
Investments in companies with negative equity:

the return is worth the risk?

2013; JFEN3 3rd / 2007; CARB5 2nd / 2001; PRVI3 2nd / 2007; BSEV3 2nd and 3rd / 2015; BAUH4 2nd and 3rd / 2008 and RIPI4 3rd / 2002 and 1st / 2008. Of the 83 component companies in the sample, 31 entered into NE and did not return to the condition of PE during the study period. That's $37 \%$.

\subsection{PORTFOLIO RESULTS}

After the construction of the portfolio, to analyze the feasibility of this type of investment, its results were compared to other investments. Moreover, as it did not take the value of money over time, compared to these investments to inflation. Thus, we compared the results of the investment in the proposed portfolio: i) to the $\mathrm{CDI}$, considered as a risk-free asset alternative. Which is based on the results obtained in the literature. ii) the $\mathrm{IBr} \times 50$, considered a similar and medium/high-risk asset, and; iii) Inflation.

Table 4A presents the annual results of the CDI investment portfolio, IBrX50, and inflation for the period, while Table 5 presents statistical data from Table 4A. Table 4B shows the accumulated results of the CDI, investment portfolio, IBrX50, and inflation of the period.

Table 4 (A and B) - Return Index - Adjusted quarterly (in percentage)

\begin{tabular}{|c|c|c|c|c|c|c|c|c|c|}
\hline \multicolumn{5}{|c|}{ Table 4A - Annual Return Rates* } & \multicolumn{5}{|c|}{ Table 4B - Annual Accumulated Return Index* } \\
\hline Year & IBrX50 & CDI & Inflation & Portfolio & Year & IBrX50 & CDI & Inflation & Portfolio \\
\hline 1998 & -33.2 & 28.6 & 1.65 & 13.56 & 1998 & -33.2 & 28.6 & 1.65 & 13.56 \\
\hline 1999 & 108.24 & 25.2 & 8.94 & 76.25 & 1999 & 39.1 & 61.01 & 10.74 & 100.15 \\
\hline 2000 & 0.44 & 17.3 & 5.97 & 3.95 & 2000 & 39.72 & 88.86 & 17.35 & 108.06 \\
\hline 2001 & 1.11 & 17.3 & 7.67 & -12.94 & 2001 & 41.27 & 121.53 & 26.35 & 81.14 \\
\hline 2002 & 4.91 & 19.1 & 12.53 & 7.91 & 2002 & 48.2 & 163.85 & 42.18 & 95.46 \\
\hline 2003 & 70.61 & 23.3 & 9.3 & 121.81 & 2003 & 152.85 & 225.32 & 55.4 & 333.54 \\
\hline 2004 & 29.88 & 16.2 & 7.6 & 85.58 & 2004 & 228.4 & 278.03 & 67.21 & 704.57 \\
\hline 2005 & 41.11 & 19,00 & 6.9 & -0.62 & 2005 & 363.4 & 349.85 & 78.75 & 699.54 \\
\hline 2006 & 30.63 & 15,00 & 3.14 & 89.3 & 2006 & 505.32 & 417.33 & 84.36 & 1413.52 \\
\hline 2007 & 53.29 & 11.8 & 4.46 & 113.91 & 2007 & 827.9 & 478.37 & 92.59 & 3137.50 \\
\hline 2008 & -42.27 & 12.4 & 5.9 & -45.98 & 2008 & 435.66 & 550.09 & 103.95 & 1649.03 \\
\hline 2009 & 72.3 & 9.9 & 4.31 & 54.99 & 2009 & 822.95 & 614.45 & 112.74 & 2610.82 \\
\hline 2010 & 0.09 & 9.7 & 5.91 & 3.72 & 2010 & 823.82 & 683.75 & 125.31 & 2711.69 \\
\hline 2011 & -12.26 & 11.6 & 6.5 & -17.37 & 2011 & 710.58 & 774.67 & 139.96 & 2223.23 \\
\hline 2012 & 13.86 & 8.4 & 5.84 & -22.44 & 2012 & 822.95 & 848.14 & 153.97 & 1701.79 \\
\hline 2013 & -3.54 & 8.1 & 5.91 & -5.33 & 2013 & 790.27 & 924.94 & 168.98 & 1605.67 \\
\hline 2014 & -2.4 & 10.8 & 6.41 & -29.84 & 2014 & 768.87 & 1035.63 & 186.22 & 1096.63 \\
\hline 2015 & -9.38 & 13.2 & 10.67 & -18.87 & 2015 & 687.39 & 1185.54 & 216.76 & 870.82 \\
\hline 2016 & 30.04 & 14,00 & 6.29 & 32.1 & 2016 & 923.93 & 1365.51 & 236.69 & 1182.43 \\
\hline 2017 & 25.32 & 9.93 & 2.95 & 16.18 & 2017 & 1183.14 & 1511.04 & 246.62 & 1389.91 \\
\hline 2018 & 17.36 & 6.42 & 3.75 & 4.55 & 2018 & 1405.87 & 1614.47 & 259.62 & 1457.64 \\
\hline 2019 & 26.97 & 5.96 & 4.31 & 44.04 & 2019 & 1812.08 & 1716.65 & 275.12 & 2143.58 \\
\hline
\end{tabular}

Source: Research data. 
José Antonio Cescon, Roberto Frota Decourt e Luciana de Andrade Costa

Table 5 - Annual Return Index Statistics (in percentage)

\begin{tabular}{ccccc}
\hline Investment & Average* & Standard deviation & Minimum & Maximum \\
\hline IBrX50 & 14.35 & 35.24 & -42.27 & 108.24 \\
CDI & 14.09 & 6.04 & 5.96 & 28.6 \\
Inflation & 6.19 & 2.57 & 1.65 & 12.53 \\
Portfolio & 15.19 & 47.71 & -45.98 & 121.81 \\
\hline
\end{tabular}

* For average, the annual values were transformed into logarithms.

Source: Research data.

The average return was, for the CDI, 14.09; for IBrX50, 14.35; and for the portfolio, 15.19 , with a standard deviation of 6.04 for the CDI, which represents a variation of $43 \%$ of its average. For the IBrX50 and the portfolio, a standard deviation of 35.24 (IBrX50) and 47.71 (portfolio) was obtained, which represents more than twice the mean value of IBrX50 and three times the mean value of the portfolio. The lowest percentage of CDI annual income (5.96) was in 2019; of the IBrX50, the lowest income (-42.27) was in 2008; and the portfolio (45.98) was also in 2008, the year of the global economic crisis. The largest return on CDI (28.60) was in 1998; of IBrX50 (108.24) in the year 1999; and the portfolio (121.81), in the year 2003.

Figure 1 shows a comparison of the annual performance of these indicators.

Figure 1 - Comparison of Annual Returns

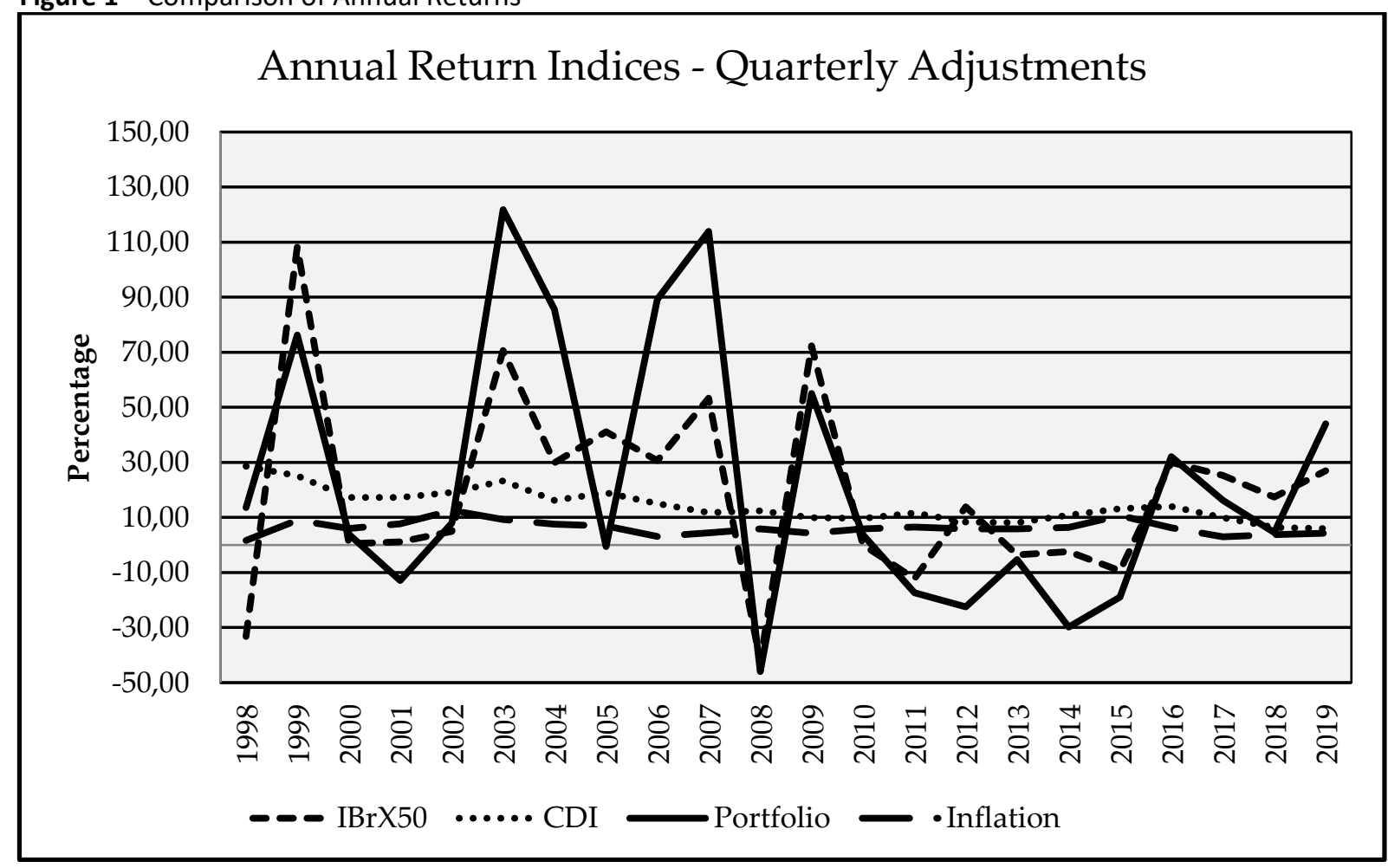

Source: Research data.

It is observed in figure 1 that the IBrX50 index trend line was accompanied by the line of the Portfolio, with the IBrX50 having a higher positive performance in 1999, 2009, 2017, and 2018. The Portfolio, in turn, had a positive annual performance higher in 2003, 2004, $2006,2007,2016$, and 2019. in other years, the best annual performance was the CDI.

This analysis allowed us to see that capital market investments respond to the global economic crisis in 2001 and 2002 with the scandals, mainly of the American companies Enron 
Investments in companies with negative equity:

the return is worth the risk?

and WorldCom, that affected the capital market in the United States (BODIE et al., 2015), and in 2008, with the Subprime crisis in the US real estate market (NOGUEIRA; GAIO, 2014, BODIE et al., 2015).

The continuous decline from 2010 to 2015 can be explained by the fall in commodity values and the reflection on the delay in the world economy resuming its growth after the 2008 crisis (BREDOW; LELIS; CUNHA, 2017), allied to the domestic situation in Brazil, which culminated in the greatest economic crisis in the history of Brazil (2014/2015/2016), with a sharp decline in Gross Domestic Product - GDP $(0.5 \%$ in 2014, -3.8\% in 2015 and $-3.6 \%$ \% in 2016) and a positive GDP recovery of $1.06 \%$ in 2017, 1.10\% in 2018 and $1.12 \%$ in 2017 (IBGE, 2020).

The analysis of investments up to the present is restricted to the annual evolution of these investments. The following are the cumulative returns of investments from January 1998 to December 2019. Although the investment portfolio proposed in this study was adjusted quarterly, the results were analyzed annually.

Due to its remuneration characteristic, the investment in CDI did not have negative returns. In this sense, their cumulative returns were increasing to a greater or lesser extent. Investments in the IBrX50 and the portfolio, due to their remuneration characteristics - which are subject to capital market risks - presented greater variability in the period of this study.

Figure 2 shows the accumulated evolution of the portfolio of investments with the other indicators presented in Table 4B.

Figure 2 - Comparison of Accumulated Annual Returns

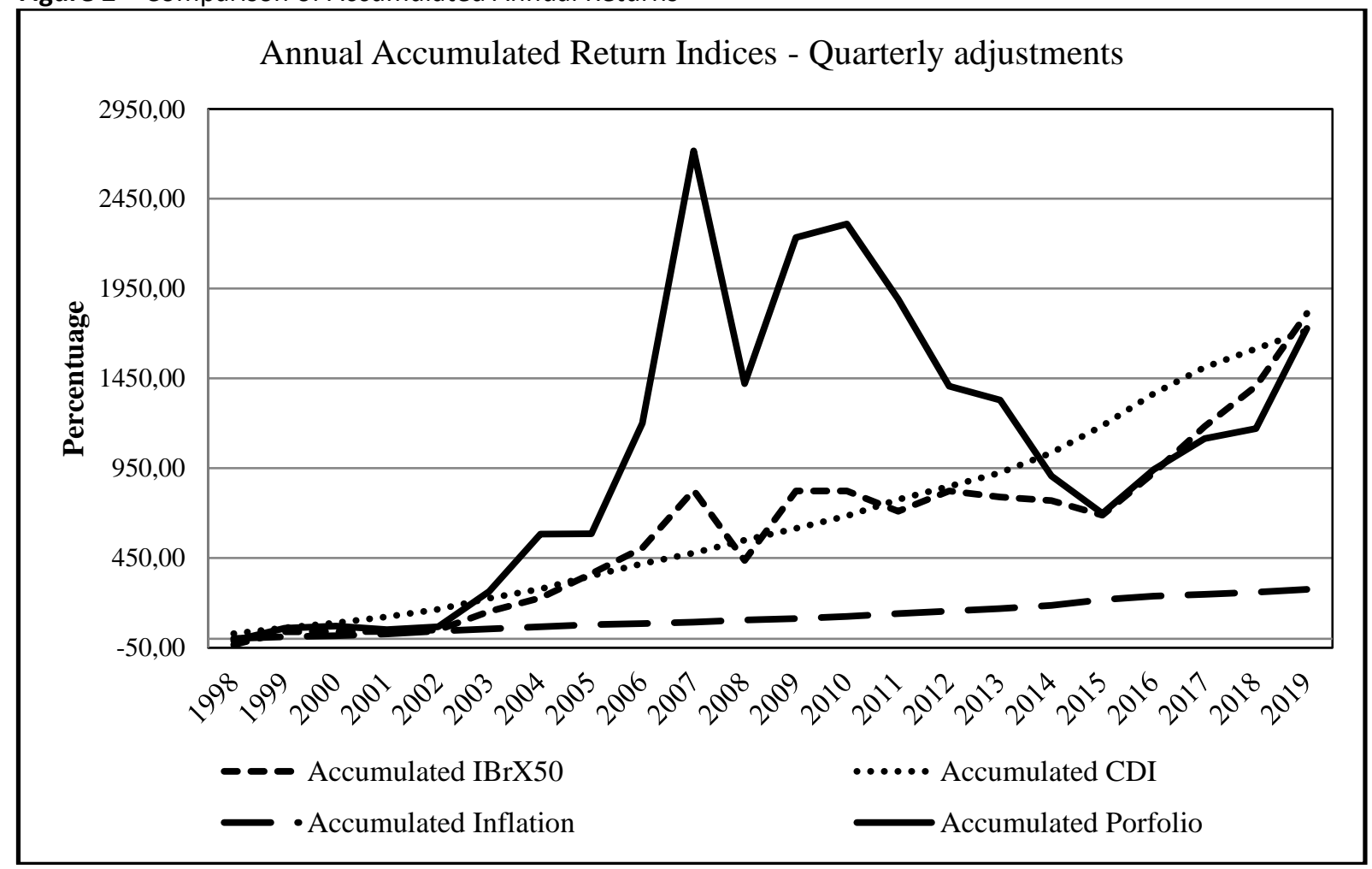

Source: Research data.

According to the data in Table 4, at the end of the initial year of the 1998 series, the cumulative return on the portfolio (13.56\%) was lower than the yield reached by the CDI (28.60\%). The IBrX50 obtained a negative income (-33.20\%).

With a comparative analysis of the evolution of the accumulated income between the $\mathrm{IBrX50}$ and the portfolio, the IBrX50 had its highest remuneration $(1812.08 \%)$ reached at the 
end of the series. The portfolio had its highest remuneration in 2007 (2717.14\%), and its performance at the end of the series (2019) was $1728.90 \%$, which represents only $63.63 \%$ of the compensation obtained in 2007.

Another noteworthy fact is that both investments (IBrX50 and portfolio) suffered a considerable and very similar loss in 2008. The IBrX50 had a cumulative loss of $47.37 \%$, and the portfolio a loss of $47.44 \%$ in relation to 2007 . Unlike the portfolio, the IBrX50 obtained a recovery in 2009 , being only $0.6 \%$ of the accumulated income earned in 2007 . The portfolio did not obtain the same recovery, being $-17.78 \%$ of the accumulated income achieved in 2007 .

As of 2010, the accumulated returns of the IBrX50 and the portfolio had a slightly different behavior between the two. The IBrX50 oscillated less between 2009 and 2015, returning to continuous growth from 2016 to 2019, in this period having its biggest and worst accumulated return after 2008 was in 2019. The portfolio showed a steady decline in accumulated returns from 2010 to 2015, with a growing recovery from 2016 to the end of the series in 2019. Based on the accumulated return provided by the Portfolio, the next step was to analyze from the perspective of risk whether investing in companies that have and / or have $\mathrm{NE}$ is a viable investment.

For Markowitz (1952), investors consider or should consider the expected return of an investment as desirable and the variance of that return as undesirable. According to Bodie et al. (2015), the diversification of investments requires the acceptance of certain risks in exchange for the prospect of obtaining a higher rate than in a risk-free investment.

In this sense, what is expected is that investors determine the price of risky assets so that the risk premium is proportional to the risk of that expected excess return, and it is, therefore, better to measure the risk by the standard deviation of the returns in and not simply through the total returns of each investment (BODIE et al., 2015).

To better understand the results analyzed so far, it was necessary to deepen the analysis. In this sense, for the analysis of the risk-adjusted return of the Portfolio, the analysis of the Sharpe Index of these investments was added.

\subsection{SHARPE INDEX ANALYSIS}

For the calculation of the Portfolio Sharpe Index and the IBrX50, the CDI was used as a risk-free asset. To calculate the market Beta of a share, the market index is used, in this case, the Bovespa Index (IBOVG).

The Sharpe Index is expressed as:

$$
\text { IS } \left.=\frac{(\text { Return on investment }- \text { Return on risk-free rate) }}{\text { The standard deviation of return on investment }} \text { (equation } 1\right)
$$

Table 6 shows the total returns, annual return, and annual risk of the investments, as well as the Sharpe indices in relation to the CDI as a risk-free asset.

Table 6 - Return results and Sharpe index

\begin{tabular}{ccccc}
\hline \multicolumn{5}{c}{ Full base: January/1998 - December/2019 } \\
\hline Indicators & CDI & Portfolio & IBrX50 & IBOVG \\
\hline Total Return & 1710.37 & 2159.99 & 1703.46 & 1247.14 \\
\hline Annual Return & 14.07 & 15.23 & 14.05 & 12.55 \\
\hline Annual Risk & 1.62 & 29.66 & 23.46 & 25.64 \\
\hline CDI Sharpe Index & - & 0.04 & 0 & -0.06 \\
\hline
\end{tabular}

Source: Research data. 
Investments in companies with negative equity:

the return is worth the risk?

Using the $\mathrm{CDI}$ as a reference for evaluating other investments, it can be seen that the indicators were 0.04 in relation to the portfolio, 0 in relation to the $\mathrm{IBrX50}$, and -0.06 in relation to the IBOVG. In this case, both investments do not add any gain to the investment against each percentage of risk assumed. By analyzing the Sharpe Index, it is observed that, given the risk, the portfolio, the IBrX50 and the IBOVG are not investments that can compete in terms of the risk/return relationship with the CDI.

The analysis of the Sharpe Index, which was performed annually from december 1999, with 24 months of observations, is shown in Table 7.

Table 7 - Sharpe index, full base and last 24 months, series 1998 to 2019

\begin{tabular}{|c|c|c|c|c|c|c|c|c|c|c|c|}
\hline \multicolumn{12}{|c|}{ Return / Risk - Sharpe's Index with Risk Free (CDI) Full-base and annualized series with 24 months of lag } \\
\hline & \multicolumn{4}{|c|}{ Annual Return* } & \multicolumn{4}{|c|}{ Annual Risk* } & \multicolumn{3}{|c|}{ Sharpe CDI Index } \\
\hline & CDI & Portfolio & IBrX50 & IBOVG & $\mathrm{CDI}$ & Portfolio & $\mathrm{IBrX50}$ & IBOVG & Portfolio & IBrX50 & IBOVG \\
\hline $\begin{array}{l}\text { Full } \\
\text { base }\end{array}$ & 14.07 & 15.23 & 14.05 & 12.55 & 1.62 & 29.66 & 23.46 & 25.63 & 0.04 & 0 & -0.06 \\
\hline Dec./99 & 26.84 & 41.99 & 17.94 & 21.27 & 1.84 & 34.77 & 48.78 & 48.56 & 0.44 & -0.18 & -0.11 \\
\hline Dec./00 & 21.16 & 35.85 & 44.62 & 37.91 & 1.68 & 35.27 & 35.63 & 37.9 & 0.42 & 0.66 & 0.44 \\
\hline Dec./01 & 17.3 & -4.87 & 0.78 & -7.2 & 0.46 & 33.94 & 23.82 & 28.32 & -0.65 & -0.69 & -0.86 \\
\hline Dec./02 & 18.17 & -3.08 & 2.99 & -12.92 & 0.56 & 24.87 & 20.53 & 26.41 & -0.85 & -0.74 & -1.18 \\
\hline Dec./03 & 21.16 & 54.71 & 33.78 & 26.46 & 0.82 & 23.88 & 17.62 & 24.73 & 1.40 & 0.72 & 0.21 \\
\hline Dec./04 & 19.66 & 102.89 & 48.86 & 52.46 & 1.07 & 34.76 & 17.48 & 21.66 & 2.39 & 1.67 & 1.51 \\
\hline Dec./05 & 17.57 & 35.80 & 35.38 & 24.5 & 0.51 & 36.51 & 18.66 & 18.68 & 0.50 & 0.95 & 0.37 \\
\hline Dec./06 & 17 & 37.16 & 35.77 & 31.1 & 0.67 & 27.91 & 18.71 & 16.64 & 0.72 & 1 & 0.79 \\
\hline Dec./07 & 13.41 & 101.23 & 41.51 & 37.85 & 0.59 & 31.49 & 19.06 & 17.23 & 2.79 & 1.47 & 1.42 \\
\hline Dec./08 & 12.09 & 7.50 & -5.93 & -6.7 & 0.36 & 38.88 & 29.96 & 28.32 & -0.12 & -0.6 & -0.66 \\
\hline Dec./09 & 11.11 & -8.49 & -0.27 & 3.77 & 0.52 & 30.37 & 29.87 & 29.73 & -0.65 & -0.38 & -0.25 \\
\hline Dec./10 & 9.82 & 26.79 & 31.33 & 35.41 & 0.37 & 31.07 & 16.96 & 18.09 & 0.55 & 1.27 & 1.41 \\
\hline Dec./11 & 10.67 & -7.42 & -6.28 & -7.86 & 0.38 & 29.78 & 14.31 & 14.49 & -0.61 & -1.19 & -1.28 \\
\hline Dec./12 & 9.99 & -16.95 & -2.92 & -6.87 & 0.53 & 15.93 & 14.1 & 15.97 & -1.69 & -0.92 & -1.06 \\
\hline Dec./13 & 8.23 & -11.03 & 1.78 & -5.9 & 0.36 & 16.76 & 13.87 & 16.8 & -1.15 & -0.47 & -0.84 \\
\hline Dec./14 & 9.43 & -18.05 & -2.97 & -8.58 & 0.47 & 16.84 & 15.31 & 16.3 & -1.63 & -0.81 & -1.1 \\
\hline Dec./15 & 12.04 & -21.41 & -5.96 & -6.13 & 0.44 & 18.47 & 15.05 & 15.09 & -1.81 & -1.2 & -0.2 \\
\hline Dec./16 & 13.63 & 9.62 & 8.56 & 9.24 & 0.31 & 28.67 & 20.11 & 20.57 & -0.14 & -0.25 & -0.21 \\
\hline Dec./17 & 11.81 & 14.53 & 27.66 & 28.82 & 0.7 & 27.03 & 19.44 & 19.76 & 0.1 & 0.82 & 0.86 \\
\hline Dec./18 & 8.02 & 18.39 & 21.27 & 36.07 & 0.59 & 23.56 & 15.75 & 29.62 & 0.44 & 0.84 & 0.95 \\
\hline Dec./19 & 6.18 & 22.71 & 22.07 & 38.13 & 0.18 & 29.56 & 14.41 & 28.78 & 0,56 & 1.1 & 1,11 \\
\hline
\end{tabular}

* In percentage

Source: Research data.

Having the CDI as a risk-free asset, we can see, in Table 7, Sharpe indices were negative for the Portfolio in 10 of the 21 years, and the IBrX50 and the market (IBOVG) in 11 of the 21 years observed with emphasis on the portfolio for the years 2012 to 2015, with this negative index being higher than 1.00 .

Considering the Sharpe Index greater than 1.00, compared to risk-free assets, the performance of the Portfolio was superior to the IBrX50 and IBOVG, in the years 2003, 2004, and 2007. The IBrX50 was superior to the Portfolio in 2006, 2010 and 2019, since the IBOVG, surpassed the Portfolio in 2010, and 2019. In this case, in addition to these indices above 1.00, the years 2005, 2006, 2010, and 2019 stand out, with acceptable indices for the risk/return condition. Therefore, in $7 / 21$ periods, the return of the Portfolio would be acceptable. 
Figure 3 shows the evolution of the results of the portfolio with the operationalization of exits of the companies that returned to the Condition of PE in four different moments. The analysis to date did not include outflows of assets, except those already mentioned in the methodology.

- Exit of the portfolio asset in the first quarter following the return to the PE;

- Exit of the portfolio assets in the second quarter following the return to the PE;

- Exit of the portfolio asset in the first year following the return to the PE;

- Exit of the portfolio asset in the second year following the return to the PE.

Figure 3 - Accumulated Earnings Index - Exits at different times

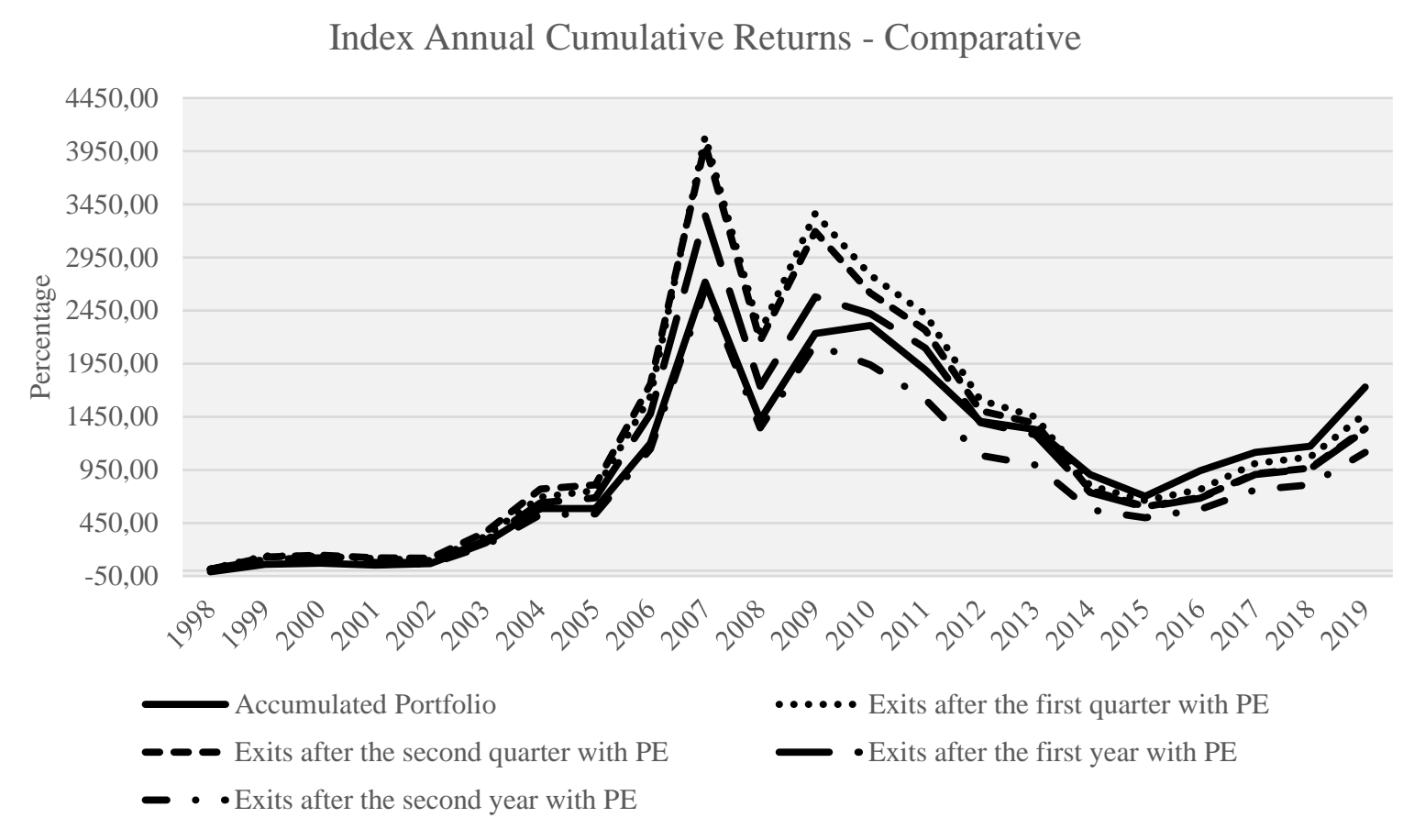

Source: Research data.

The exit data, shown in Figure 3, indicates that, until the 3rd semester of 2003, the portfolio's result had little change, regardless of when the asset was withdrawn. From the fourth-quarter of 2003 until the third-quarter of 2007, the best moment of exit occurred after two-quarters of the company's return to the condition of PE. From the 4th-quarter of 2007 to the 1st quarter of 2012, the best moment was after the first-quarter of the return to the condition of PE. From the 2nd quarter of 2012 until the end of the analysis of the series, the best return was when there was no exit at any moment due to the return to the condition of PE.

Given the results presented by the proposed portfolio and, in comparison to the other investments, it was verified that it is possible to obtain positive abnormal returns of investments through the construction of a portfolio of Investments constituted, exclusively, by companies with NE listed in B3. It was also verified that the return of this portfolio gave returns higher than a risk-free Investment (CDI) or similar investment (IBrX50).

However, it was also found that these returns do not justify the risk assumed in the period and returns obtained by the portfolio from 2003 to 2007 provided abnormal returns consistent with the risk of this investment, as well as that, although in 2008 a sharp drop in the portfolio's accumulated gain, this was still much higher than the other investments 
Investments in companies with negative equity:

the return is worth the risk?

analyzed and showing likewise a recovery of profit in 2009 and 2010. As of 2011, the returns obtained by the portfolio do not justify the risk assumed.

It is concluded that in Brazil, because of the high risk-free rate, risky investments do not make meaning. However, when compared to other risky investments, investing in companies with NE may make sense, as a portfolio with no judgment criteria has a risk-return ratio more attractive than stock indexes (IBrX50). Thus, even with the high risk of the negative equity portfolio, this investment may be interesting even for conservatives, since the addition of some of these assets in a conservative portfolio may even reduce the portfolio risk and improve the expected return.

A possible explanation for these companies to have an active market, is the study by Coelho (2015), that the market stops processing the bankruptcy signal until 6 months after the company filed for bankruptcy. This finding is inconsistent with the efficient market hypothesis (FAMA, 1970).

\section{FINAL REMARKS}

Considering the hypothesis of investor rationality, the asset market in the stock market for companies with financial difficulties, especially for companies with NE, should theoretically not be active or provide abnormal positive returns to investors, since, technically, the companies would be insolvent. This is not the case in Brazil, since there are even a relatively large number of companies in this situation with an active market and, as demonstrated in this study, investors can obtain abnormal positive returns with investments in these companies. These results corroborate the findings of Jan and Ou (2012).

The results show that there are abnormal positive returns for the companies mentioned and that, in certain moments, these returns far outweigh the risk-free investments used for comparison purposes. Getting abnormal positive returns is not the only criterion for considering such a good business investment. One must take into consideration the risks involved in such an investment. Thus, along with these abnormal returns, the risk inherent in this investment was verified. In the full series of the investment portfolio (22 years), the portfolio's annual risk stood at $29.66 \%$, the IBrX50 at $23.46 \%$, and the CDI at $1.62 \%$.

By relating these risks to the average annual returns, in which the investment portfolio provided an average annual return of $15.23 \%$, the $\mathrm{IBrX50}$, an average annual return of $14.05 \%$, and the $\mathrm{CDI}$, an average annual return of $14.07 \% \%$, it can be seen that both the investment portfolio and the IBrX50 did not provide returns consistent with the risks of these investments and that only the $\mathrm{CDI}$ presented the acceptable risk/return ratio.

To validate the analysis of this portfolio, the accumulated general and annualized results (with a 24-month lag) were submitted to the Sharpe Index. Using the CDI as a reference (risk-free), it was noticed that the indicators were 0.04 in relation to the portfolio and to the IBrX50. In this case, both investments did not add any gain to the investment against each percentage of risk assumed. Through these analyses of the investment portfolio proposed in this study, it is concluded that investments in companies with NE are not an investment that provides returns compatible with risk-free investment (CDI).

Through the results of this study and the premises of the studies by Jan \& Ou (2012), it must be considered that investors have other motivations to invest in companies with $\mathrm{NE}$. Cescon, Decourt \& Costa (2020), analyzed the decision-making process of investors and financial market analysts in investments in companies with NE. The results showed there is an influence of behavioral biases in this process. 
Still, investment in a company with PLN can be explained by Han and Kumar (2013), who in their studies report that stocks with speculative characteristics (ie, low price, high idiosyncratic asymmetry, and volatility) are the preferred habitat of retail investors with a strong propensity to play. This is corroborated by Coelho et al. (2014), who analyzed the main characteristics of bankrupt companies, the results suggest that it is likely that there is a natural demand for the shares of bankrupt companies, that is, demand from retail investors who trade such securities as if they were betting on the market.

This study contributes to the literature in addition to bringing to the academic world the universe of companies with NE notably concerning the returns that these companies can provide to investors and still be an unprecedented study in this approach in Brazil.

Regarding the limitations of this study, it should be mentioned the original historical values were not deflated and the assets' values do not contemplate payments of dividends (the market efficiency is assumed here). Given these limitations, our results cannot be generalized. In future studies of companies with $\mathrm{NE}$, it can be investigated whether there are financial-economic indicators in these companies that can justify their positive market value, as well as whether these indicators can justify abnormal returns for these firms, as developed in Jan and Ou (2012) study.

\section{REFERENCES}

ANG, T. C. C. Are Firms with Negative Book Equity in Financial Distress? Review of Pacific Basin Financial Markets and Policies, Singapura, v. 18, n. 03, p. 1550016, 2015. DOI: https://doi.org/10.1142/S0219091515500162.

ANTUNES, G. A.; LAMOUNIER, W. M.; BRESSAN, A. A. Análise do "efeito tamanho" nos retornos das ações de empresas listadas na Bovespa. Revista Contabilidade \& Finanças, São Paulo, v. 17, n. 40, p. 87-101, 2006. DOI: https://doi.org/10.1590/S1519-

70772006000100007.

Brasil, Bolsa e Balcão (B3). Índice Bovespa. Índice IBrX50. São Paulo, 2020. Disponível em: http://www.bmfbovespa.com.br/ptbr/produtos/ indices/indices-amplos/indice-brasil-50ibrx-50-estatisticas-historicas.htm. Acesso em: 04 nov. 2020.

BODIE, Z. KANE, A. MARCUS, A. J. Investimentos. Porto Alegre: Bookman, 2015.

BREDOW, S. M. S.; LÉLIS, M. T. C.; CUNHA, A. M. O ciclo de alta nos preços das commodities e a economia brasileira: uma análise dos mecanismos externos de transmissão entre 2002 e 2014. Economia e Sociedade, Campinas, v. 25, n. 3, p. 695-731, 2017. DOI: https://doi.org/10.1590/1982-3533.2016v25n3art7.

BROWN, S.; LAJBCYGIER, P.; LI, B. Going Negative: What to Do with Negative Book Equity Stocks (Digest Summary). Journal of Portfolio Management, London, v. 35, n. 1, p. 95-102, 2008. DOI: https://doi.org/10.3905/JPM.2008.35.1.95.

CERETTA, P. S.; COSTA JR, NCA. Quantas ações tornam um portfólio diversificado no mercado de capitais brasileiro. Mercado de Capitais-Análise Empírica no Brasil-Coleção Coppead de Administração, Rio de Janeiro, 2000. 
Investments in companies with negative equity:

the return is worth the risk?

CESCON, J. A.; DECOURT, R. F.; COSTA, L. A. Análise do processo decisório dos investidores e analistas do mercado financeiro em relação às ações de empresas com patrimônio líquido negativo. Revista Contemporânea de Contabilidade, Florianópolis, v. 17, n. 43, p. 51-70, 2020. DOI: https://doi.org/10.5007/2175-8069.2020v17n43p51.

COELHO, L. M. S. Bad news does not always travel fast: evidence from Chapter 11 bankruptcy filings. Accounting \& Finance, Melbore, v. 55, n. 2, p. 415-442, 2015. DOI: https://doi.org/10.1111/acfi.12063.

COELHO, L. M. S.; JOHN, K.; KUMAR, A.; TAFFLER, R. Bankruptcy Sells Stocks... But Who's Buying (and Why)? Miami, 2014. Available at SSRN:

https://ssrn.com/abstract=2427770 or DOI: http://dx.doi.org/10.2139/ssrn.2427770

COLLINS, D. W.; PINCUS, M.; XIE, H. Equity valuation and negative earnings: The role of book value of equity. The Accounting Review, Kansas City, v. 74, n. 1, p. 29-61, 1999. DOI: https://doi.org/10.2308/accr.1999.74.1.29

DONNELLY, R. The book-to-market ratio, optimism and valuation. Journal of Behavioral and Experimental Finance, Noruega, v. 4, p. 14-24, 2014. DOI:

https://doi.org/10.1016/j.jbef.2014.10.002.

EASLEY, D.; O'HARA, M. Information and the cost of capital. The Journal of Finance, Hoboken, v. 59, n. 4, p. 1553-1583, 2004. DOI: https://doi.org/10.1111/j.15406261.2004.00672.x

EVANS, J. L.; ARCHER, S. H. Diversification and the reduction of dispersion: an empirical analysis. The Journal of Finance, Hoboken, v. 23, n. 5, p. 761-767, 1968.

DOI: https://doi.org/10.1111/j.1540-6261.1968.tb00315.x

FAMA, E. F. Efficient capital markets: a review of theory and empirical work. The Journal of Finance, Hoboken, v. 25, n. 2, p. 383-417, 1970. DOI: https://doi.org/10.1111/j.15406261.1970.tb00518.x

FAMA, E. F. Efficient capital markets: II. The Journal of Finance, Hoboken, v. 46, n. 5, p. 1575-1617. 1991. DOI: https://doi.org/10.1111/j.1540-6261.1991.tb04636.x

FAMA, E. F.; FRENCH, K. R. The cross-section of expected stock returns. The Journal of Finance, Hoboken, v. 47, n. 2, p. 427-465. 1992. DOI: https://doi.org/10.1111/j.15406261.1992.tb04398.x

FAMA, E. F.; FRENCH, K. R. Common risk factors in the returns on stocks and bonds. Journal of Financial Economics, New York, v. 33, n. 1, p. 3-56. 1993.

FARIAS, A. E.; CERETTA, P. S.; ROSA, R. M. da. Testes de quociente de variâncias do caminho aleatório no Ibovespa e no S\&P 500. In Congresso USP de Controladoria e Contabilidade (Vol. 9). São Paulo. 2009. 
FERREIRA, L. C. D.; OLIVEIRA, B. C. Efeito no preço das ações com o anúncio de ofertas subsequentes de ações de empresas brasileiras. Revista de Finanças Aplicadas, São Paulo, v. 1, p. 1-18. 2014.

GABRIEL, F. S.; RIBEIRO, R. B.; RIBEIRO, K. C. S. Hipóteses de mercado eficiente: um estudo de eventos a partir da redução do IPI. Revista de Gestão, Finanças e Contabilidade, Salvador, v. 3, n. 1, p. 36, 2013. DOI: http://dx.doi.org/10.18028/rgfc.v3i1.95.

GRILLO, F. F.; LACHINI, T. C.; BAIOCO, V. G., REINA, D.; NETO, A. Value Relevance: Análise dos efeitos da avaliação a valor justo. ConTexto, Porto Alegre, v. 16, n. 32, 2016.

HAN, B.; KUMAR, A. Speculative retail trading and asset prices. Journal of Financial and Quantitative Analysis, Cambridge, v. 48, n. 2, p. 377-404, 2013.

DOI: https://doi.org/10.1017/S0022109013000100.

HAUGEN, R. A. Os segredos da bolsa: como prever resultados e lucrar com ações. São Paulo: Pearson Brasil, 2005.

HAYN, C. The information content of losses. Journal of Accounting and Economics, Massachusets, v. 20, n. 2, p. 125-153, 1995.

HODGES, C. W.; TAYLOR, W. RL; YODER, J. A. Beta, the Treynor ratio, and long-run investment horizons. Applied Financial Economics, London, v. 13, n. 7, p. 503-508, 2003. DOI: https://doi.org/10.1080/0960310022000016622.

HOU, K.; ZHANG, Y.; ZHUANG, Z. Understanding the Variation in the Information Content of Earnings: A Return Decomposition Analysis. Fisher College of Business Working Paper, Ohio, n. 2015-03, p. 01, 2015. DOI: https://dx.doi.org/10.2139/ssrn.2548688.

IBGE. Produto Interno Bruto. Disponível em: http://saladeimprensa.ibge.gov.br/ noticias?view=noticia\&id=1\&busca=1\&idnoticia=3384. Brasilia, 2018. Acesso em: 08 set. 2020.

JAN, C. L.; OU, J. A. Negative-book-value firms and their valuation. Accounting Horizons, Kansas City, v. 26, n. 1, p. 91-110, 2012. DOI: https://doi.org/10.2308/acch-50094.

JENSEN, M. C. Some anomalous evidence regarding market efficiency. Journal of Financial Economics, New York, v. 6, n. 2/3, p. 95-101, 1978. DOI: https://dx.doi.org/10.2139/ssrn.244159.

LINTNER, J. The Valuation of Risk Assets and the Selection of Risky Investments in Stock Portfolios and Capital Budgets. The Review of Economics and Statistics, Massachusets, v. 47, n 1, 1965. DOI: https://doi.org/10.1016/B978-0-12-780850-5.50018-6.

MARKOWITZ, H. Portfolio selection. The Journal of Finance, Hoboken, v. 7, n. 1, p. 77-91, 1952. 
Investments in companies with negative equity:

the return is worth the risk?

MERTON, R. C. Theory of rational option pricing. The Bell Journal of economics and management science, Santa Monica, p. 141-183, 1973.

MÜLLER, F. M.; RIGHI, M. B.; CERETTA, P. S. Ibovespa market efficiency analysis: A quantile autoregressive model approach. Revista Base São Leopoldo, v. 12, n. 2, 122-134. 2015. DOI: https://doi.org/10.4013/base.2015.122.04.

NGUYEN, T.; STALIN, O.; DIAGNE, A.; AUKEA, L.; ROOTZEN, P. H.; HERBERTSSON, A. The Capital asset pricing model and the Arbitrage pricing theory. Report. Gothenburg University, Gothenburg, p. 1-11, 2017.

NOGUEIRA, K. B. L.; GAIO, L. E. Impacto da Crise dos Subprimes nas Empresas da BM\&FBovespa: Uma Análise fundamentalista. Nucleus, Ituverava, v. 11, n. 2, p. 341-351, 2014. DOI: http://dx.doi.org/10.3738/1982.2278.1061.

OSBORNE, MF M. Brownian motion in the stock market. Operations research, London, v. 7, n. 2, p. 145-173, 1959. DOI: https://doi.org/10.1287/opre.7.2.145.

RÊGO, R. H. T.; MUSSA, A. Anomalias do mercado acionário: a verificação do efeito feriado no IBOVESPA E IBX-100 no período de 2002 a 2007. In Congresso USP de Controladoria e Contabilidade. São Paulo, 2008.

RIGHI, M. B.; CERETTA, P. S. Testes de Quocientes de Variância do Caminho Aleatório nos Indices Setoriais Brasileiros. Revista Base, São Leopoldo, v. 11, n. 2, p. 167-177, 2014. DOI: http://dx.doi.org/10.4013/base.2014.112.06.

ROBERTS, H. V. Stock-Market "Patterns" And Financial Analysis: Methodological Suggestions. The Journal of Finance, Hoboken, v. 14, n. 1, p. 1-10, 1959. DOI:

http://dx.doi.org/10.2307/2976094.

ROCHMAN, R. R.; EID JR, W. Insiders conseguem retornos anormais? Estudos de eventos sobre as operações de insiders das empresas de governança corporativa diferenciada da Bovespa. Anais do Encontro Brasileiro de Finanças, São Paulo, 2007.

ROMA, C. M. S.; FERREIRA, B. P.; AMARAL, H. F. Testando a Forma Fraca de Eficiência na Taxa de Câmbio (BRL/USD). Revista de Administração FACES Journal, Belo Horizonte, v. 13, n. 3, 2015.

ROSS, S. A. The arbitrage theory of capital asset pricing. Journal of Economic Theory, Philadelphia, v. 13, n. 3, p. 341-360, 1976.

SHARPE, W. F. Capital asset prices: A theory of market equilibrium under conditions of risk. The Journal of Finance, Hoboken, v. 19, n. 3, p. 425-442, 1964. DOI: https://doi.org/10.1111/j.1540-6261.1964.tb02865.x.

SHLEIFER, A. Inefficient markets: An introduction to behavioral finance. OUP Oxford, 2000. 
SIMON, H. A. Theories of decision-making in economics and behavioral science. American Economic Review, Pittsburgh, 49, 253-283, 1957.

STATMAN, M. How many stocks make a diversified portfólio? Journal of Financial and Quantitative Analysis, London, v. 22, n. 3, p. 353-363, 1987. DOI:

https://doi.org/10.2307/2330969.

STRONG, R. A. Practical investment management. 4. ed, Boston: Thomson, South-Western, 2007.

TIMMERMANN, A.; GRANGER, C. WJ. Efficient market hypothesis and

forecasting. International Journal of forecasting, Medford, v. 20, n. 1, p. 15-27, 2004.

ZHOU, H.; ELLIOTT, R. J.; KALEV, P. S. Information or noise: What does algorithmic trading incorporate into the stock prices? International Review of Financial Analysis, Oslo, v. 63, p. 27-39, 2019. 